\title{
Greeks and »Greek« Writers in the Early Medieval Italian Papyri
}

\section{Edward M. Schoolman*}

This article examines the instances when Greek script was used in the sixth- and seventh-century papyri documents originally preserved as part of the archive of the church of Ravenna. In interpreting these instances, we find both reflections of larger political events and smaller personal choices against the backdrop of continued migration from the Byzantine east to Italy following the conquest of the Ostrogothic kingdom by the armies of Justinian in the middle of the sixth century and the establishment of an exarchate dominated by military officials with various levels of clear "Greek" identity - political, hereditary, religious, and linguistic. Within this framework, participants in the creation of legal documents who were identified as grecus or wrote in Greek script did so for individual and micropolitical reasons that were distinct from conveying an ethnic identity, highlighting differences brought on by the situations in which they participated.

Keywords: Byzantine Italy, Naples, literacy, linguistic identity, ethnic identification, Italian papyri, migration and acculturation

Beginning in 536, the armies of the eastern Roman Empire undertook an invasion and reconquest of the Italian peninsula; by 540 the Ostrogothic kingdom had collapsed, leading to more than a decade of guerilla warfare against the surviving Gothic force. At the conclusion of these hostilities, new groups of easterners who we might identify as "Greeks" in origins and linguistic preference had settled in Italy, primarily in its administrative centers now under the control of the emperor in Constantinople. ${ }^{1}$ With the imposition of this new regime and the integration of soldiers and administrators to areas that possessed longstanding Greek-speaking communities, minorities, and religious institutions, the boundaries of "Greek" identity became harder to interpret, especially given the longstanding practice of using grecus as a pejorative epithet or as a veiled insult. ${ }^{2}$ Even more complex in this context were ideas related to the simultaneous applications of Romanness and Greek or Hellenic

* Correspondence details: Edward M.Schoolman, University of Nevada, Reno, 1664 N. Virginia St, Reno NV 895570308, USA, eschoolman@unr.edu.

1 On the origins of migrants in Italy during this period and various approaches to assessing or measuring the arrival of eastern populations, see Brown, Gentlemen and Officers, 65-69; Guillou, Régionalisme et indépendance, 78-80. In addition to people, physical objects also moved to Italy from the east before and after the Justinianic conquest, with a number identified in Russo, La presenza degli artefici greco-costantinopolitani. 
ethnicity, a subject that has been a recent topic of considerable review. ${ }^{3}$ Although the sixth and seventh centuries offer a number of opportunities to explore these aspects, this article focuses on the manifestations of Greekness when Greek script was used or the term grecus appeared in the process of creating legal documents, in this case those that were part of the archive of the church of Ravenna.

Despite difficulties in interpretation, there can be little doubt that a man who lived in Naples named Stephanus was a grecus, absent any pejorative sense. It was a term he used to identify himself in a donation he made to the church of Ravenna, preserved in its original seventh-century papyrus, and on which he himself wrote in Latin but using Greek script. The challenges in interpreting the term grecus are: first, what did it signify when Stephanus used it himself; and second, what did it mean to those around him. This article offers some preliminary answers to these two questions by re-evaluating the connections between language choice, graphicacy (taking script, and not the language it represents, as a graphical device), and identity in the context of early Byzantine Italy, but also more broadly addresses the contexts of those who wrote using the Greek language or Greek script in the legal documents of the period. The donation offered by Stephanus offers an entry point to examine not only aspects of his own identity in the wake of migration and political reorganization in Italy, but also the limited biographical materials of his contemporary Greek speakers and writer, and how the signalling of "Greekness " was employed through graphical choices, as well as movement through and migration to the environs of Naples in particular.

Stephanus's example survives as a papyrus document preserved in two fragments in the Vatican's collection of Latin papyri documents. ${ }^{4}$ Although incomplete, it includes a large portion of the latter half of the record of the donation to the church of Ravenna. This was executed on behalf of Stephanus, described also as vir illustris and magnificus, who offered property around the town of Gubbio at the very beginning of the seventh century. Like the other donations of this period, this papyrus was prepared by a tabellio (in this case named Theodosius), who was a public notarial official of the city of Rome, as part of the registration of legal documents into the municipal gesta. ${ }^{5}$ This particular copy was likely produced to be part of the records of the church of Ravenna, kept originally to support its claim over this property against the threat that others, especially presumptive heirs who would have been removed from inheritance in favor of the church, might later contest ownership.

3 The work of Anthony Kaldellis, Johannes Koder, and Yannis Stouraitis, has complicated our understanding of the self-identities of "Greeks" as with historical, linguistic, and literary contexts, but primarily from the perspective

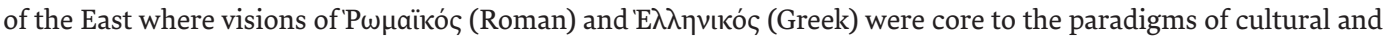
political identities. On account of the lack of self-reflective sources for the most part, these studies avoid the sixth and seventh centuries and the experiences of Byzantine Greek-speakers living in predominantly Latin-speaking areas as in central Italy under discussion here. Kaldellis, Hellenism in Byzantium; Stouraitis, Roman identity in Byzantium; Stouraitis, Byzantine Romanness; Koder, Griechische Identitäten im Mittelalter; Koder, Sprache als Identitätsmerkmal bei den Byzantinern. For notions of Hellenism of varying degrees in Naples in the following century, see Martin, Hellénisme politique.

4 P.Ital.18-19. Rome, Vatican, Biblioteca del Vaticano Pap. Lat. 16 (FrA) and 9 (FrB).

5 The gesta municipalia does not survive long after the creation of this document; however, references to the institution continue to be made through the end of the ninth century. On its operation in the sixth and seventh centuries and its afterlife, see Brown, On the Gesta municipalia; Everett, Lay documents and archives, 70-81. 
What is preserved includes the second half of the transcription of a donation declared orally by Stephanus and recorded by the notary Theodosius, then the written confirmation of the donor Stephanus (in Latin using Greek script), followed by the subscriptions of five witnesses all in their own hands and the closing of the text by the notary and his confirmation of the witnesses. No information survives from the first half of the document either about the actual gift, or when the document was created. The most recent editor of the papyri, JanOlof Tjäder, has dated this papyrus to the seventh century on paleographic grounds, and its content, form, and vocabulary tie it to the beginning of the period. ${ }^{6}$

To understand the application of grecus in the case of Stephanus, we must first examine the other aspects of his identity and their context, specifically his rank of magnificus, the witnesses he gathers to subscribe to his donation, his use of Greek script, and his mobility in Italy and citizenship in the city of Naples. To begin, although Tjäder's edition is more than satisfactory, it is worth looking in depth at this text, focusing on the best-preserved fragment beginning with the tabellio's closing of the proceedings, Stephanus's own subscription, and the first of the identical testaments of the witnesses (see table 1)

6 Tjäder, Die nichtliterarischen lateinischen Papyri Italiens, vol. I , 334-9. Commentary on this text also appears in ChLA 718 and in Crosara, P. Tjäder 18-19AB. 
Table 1: Donation of Stephanus (P. Ital 18-19.B1-34)

1 me haec omnia, quae praesens donationis textus elo[quit]ụr, inviolaviliter cons[erv]are atque adimplere, [cui] rei dolum malum abes[s]e afuturumque esse pro [mitto], eț hạnc donationis a me factae chartulam omni

$5 \quad$ [vi, dol]ọ malo, metu et circumscriptione cessante [T] heodosio v(iro) h(onesto), tabell(ioni) urb(is) Rom(ae), noto rogatarioque meo, [s]cribendam dictavi, cuique subter manu propria

[ag]novi, subscripsi, testibus a me rogịtis optuli subs[crib]endam. Allegandi etiam gestis, quibus vobis [pla]c[u]erit, et tempore, quo volueritis, non spectata [a]lia mea professione conced[o] ex [m] ore licentiam, d[e] [qua] re quibusque omnibus [stipulanti tibi, beatis][simo Domino me]o, et actori[bus s(upra)s(crip)tae s(an)c(t)ae eccl(esiae) Rav(ennatis)] [ego] Stephanus, magnif(icus) illustrius grecus donator, [in] verbis sollemnibus spopondi, et hanc donati[on]em

15 [vo]bis in praesenti contradedi. Act(um) Roma imperio, die anno et indict(ione) s(upra)s(crip)ta. + + +

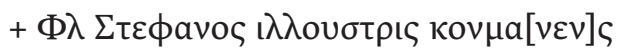

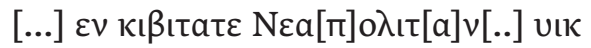

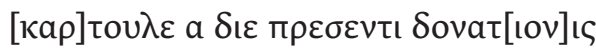

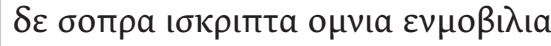

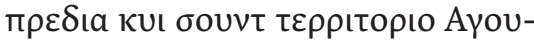

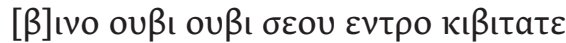

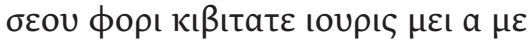

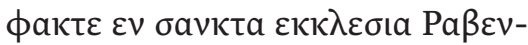

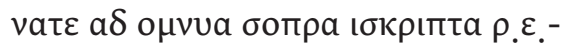

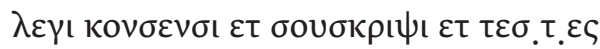

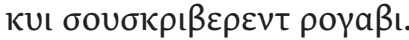
Ioannes, dom(esticus) num(eri) Dac(orum), huic chartule a die presenti donationis de s(upra)s(crip)ta

homnia inmobilia predia, que sunt territorio Agubio, seu intro cibitate seu [f]oris civitate, ubi ubi ei coppețit, facte ab Istefano magṇ[if(ico)] greco inll(ustro) in $\mathrm{s}(\mathrm{an}) \mathrm{c}(\mathrm{t}) \mathrm{a}$

30 eccç̣(esia) rabennate, sicut superius legitur, rogatus a s(upra)s(crip)to donatore, q(ui) $\mathrm{m}(\mathrm{e}) \mathrm{p}$ (raesente)

șụbṣç̣isit, ipso presente testis suscripsi, et hanc donationem in presenti [ac] toribus sce eclesị rabennatis traditam bidi. 


\begin{tabular}{|c|c|}
\hline 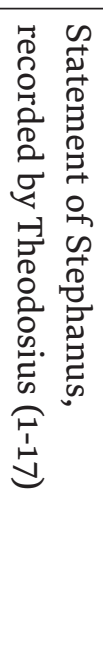 & $\begin{array}{l}\text {... to me all these thing, which being present I spoke aloud the text of the donation. } \\
\text { I promise to preserve and to execute it inviolably, to keep such a thing free of evil } \\
\text { treachery now and in the future. And with all authority, this charter of the pre- } \\
\text { pared donation, while free from evil treachery, fear, and fraud, was made by Theo- } \\
\text { dosius, the vir honestus, tabellio of the city of Rome, known and asked by me, writ- } \\
\text { ing down what I dictated. As these [proceedings] will be registered into the gesta, } \\
\text { those which might be acceptable to you and at whatever time you decide, without } \\
\text { regards to my other concerns, by declaration I grant as is the custom authority } \\
\text { over the very property and all the rest promised to you, my most reverend Lord, } \\
\text { and to the representatives of the above mentioned holy church of Ravenna, that I } \\
\text { Stephanus, magnificus illustrius grecus, the donor, promised in solemn words and } \\
\text { here I have given to you this donation. Executed in Rome, in the reign, day, year, } \\
\text { and indiction noted above. ++ + }\end{array}$ \\
\hline 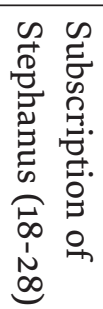 & $\begin{array}{l}\text { I, Fl(avius) Stephanus, illustris, resident in the city of Naples, present at this time in } \\
\text { which this charter of the gift [was made] over all the above mentioned real estate, } \\
\text { which is in the territory of Gubbio, whether in the city or outside of the city, made } \\
\text { by me within my right in favor of the holy church of Ravenna toward all of what is } \\
\text { mentioned above, I have thoroughly read it, I consented to its terms, and I signed, } \\
\text { and I have called for the witnesses to sign. }\end{array}$ \\
\hline 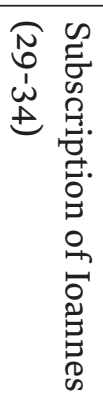 & $\begin{array}{l}\text { I, Ioannnes, domesticus (adjunct officer) of the Dacian platoon, present at this time, } \\
\text { in which this charter of the gift [was made] over all the above mentioned real es- } \\
\text { tate, which is in the territory of Gubbio, whether in the city or outside of the city, } \\
\text { wherever it happens to be, made by Stephanus magnficius grecus inllustrus in favor } \\
\text { of the holy church of Ravenna, just as it is read above, having been asked by the } \\
\text { abovementioned donor, who in my presence has undersigned, I myself signed as a } \\
\text { witness in his presence, and I saw that the donation was handed over in the pres- } \\
\text { ence of the representatives of the holy church of Ravenna. }\end{array}$ \\
\hline
\end{tabular}

The format and language of the text is consistent with other papyri donations, and in general with the other preserved texts from the corpus of Italian documentary sources. For example, Stephanus's statement points to the continuity of concerns about the subversion on account of malicious means or "evil treachery", dolus malus. This expression appears regularly in other texts, from one of the earliest papyri (P.Ital 12, from 491), which consists of donations and documents relating to gifts to the church of Ravenna read out from Ravenna's gesta municipalia (another example of which was done in 540, P.Ital 31), to receipts of land sales from 572 to 619 (P.Ital 35, 36, 38-41). 
The other feature worth noting concerns the practice of recitation in creating the document. Stephanus first completed the donation by having Theodosius "write down what I dictated ", scribendam dictavi. Like the example of keeping an exchange free of treachery, the language around the role of the notarial scribe is reflected in other texts, including both the accounts rerecording documents in the gesta (P.Ital 12 and 31). It is crucial here because it makes clear that even if Stephanus was being fed the proper formula, he clearly had the capacity to speak in Latin and did so, a point that becomes important when reviewing his own subscription.

While the format of this gift is broadly consistent with the other early medieval Italian papyri documents, it also preserved three distinct characteristics specific to the donor, Stephanus, where various aspects of his identity were mentioned or confirmed. The formal execution drawn up by the tabellio Theodosius recorded Stephanus as describing himself as magnificus illustris grecus, that is a Greek (grecus) of the highest aristocratic ranks (illustris) and the highest administrative honor (magnificus). This is the same language used by the witnesses, who included all three in their description of Stephanus. In his own subscription, Stephanus himself forgoes the magnificus and grecus, using the rank of illustris alone but including the fact that he was domiciled in Naples. We further learn from Stephanus's subscription that he included Flavius in his own address in abbreviated form, a common feature in the fourth and fifth centuries. In some circumstances, the abbreviation of $F l$. amounted to little more than a formal designation akin to "Sir" in English. While known in papyri from Egypt, there it was commonly applied in different contexts but also as a qualifier of a particular status. While the exact nature of Flavius in the case of Stephanus is certainly debatable, it likely reaffirmed his high political status. ${ }^{7}$

The use of magnificus is significant here, clearly positioning Stephanus among the most important bureaucrats and administrators in early seventh-century Byzantine Italy through the application of this honor. In the Italian papyri, magnificus only appears in three other instances all predating Stephanus; although from different contexts, its applications indicated individuals of the highest social strata. The first two instances were in a document drafted in 489 , in which a senior administrator Pierius, a comes domesticorum in the government of Odovacar (the title and position known from other sources), and a magister officiorum named Andromachus, were both described with the honor of magnificus. ${ }^{8}$ The charter was produced in Syracuse and confirmed Odovacar's gift of lands in Sicily and Dalmatia to Pierius the year before he would fall in the battle of Adda against the victorious forces of the Ostrogothic king Theoderic (P.Ital 10-11). ${ }^{9}$ After Italy rejoined the eastern Roman Empire, the title appeared once more in the papyri in a petition for guardianship in 557, made by the recent widow and illustris femina Gundihild who was seeking a legal representative in a case concerning the property that had come to her two children in Rieti. In the proceedings, the vir magnificus named Gundirit was listed as having taken an unnamed action against the deceased father (P.Ital 7)..$^{10}$ On onomastic grounds, the parties to this text were Goths or bore some Gothic identity, but still used the same ranks as their late Roman counterparts.

7 Cameron, Flavius: A nicety.

8 Andromachus 3 in PLRE II, 89 and Pierius 5 in PLRE II, 885-886.

9 Wolfram, History of the Goths, 282.

10 Gundirit in PLRE III, 564 and PIB II, 90; Amory, People and Identity, 382. On the case itself, see Everett, Lay documents and archives, 81; Tarozzi, La petitio faciendi tutoris specialis di Gundihild. 
In the 540s, Cassiodorus mentions a number of men styled as magnifici including praetorian prefects and patricians during the Ostrogothic administration of Italy, while the papal epistolary evidence from the second half of the sixth century introduces a number of individuals assigned the rank of magnificus in the letters of Popes Pelagius (556-561) and Gregory (590-604). Their occupations varied, but all were high-ranking administrators, and many were responsible for entire cities and regions: Aemilianus was a magister militum; Constantinus was presumably the governor of Apulia and Calabria; Leo (who later was styled as vir gloriosus), was the praetor Siciliae; Maurentius was a chartularius, traveling to Rome, but likely based in Sicily; and Severus was the scholasticus of the exarch. ${ }^{11}$ The list of magnifici is undoubtedly longer, although Pope Gregory also uses the term adjectively to describe personal qualities, so clarifying its application becomes complex. Ultimately, while no sources reported on how they might have used their ranks and titles in documents, it is with this cohort that we can place Stephanus.

The other identifying "rank « is that of illustris, or as it often appears, inlustris. Although it had been the highest of the senatorial ranks in the fourth century, by the end of the sixth century it had come to be used simply to demarcate elevated status within the imperial administration, and was especially common during the Gothic period. ${ }^{12}$ Because illustris could be employed by those in a wide range of services and positions, and because, unlike magnificus, it had inheritable elements, it appears with much greater frequency, including instances in seven of the Italian papyri. The application of it here simply reaffirms Stephanus's permanent elevated status, as it is what he uses to define himself rather than the earned rank of magnificus.

Beyond his titles, the men asked by Stephanus to witness the act of his donation provide a window in the networks to which he belonged, one in which friendship, occupational status, and hierarchical relationships all could play a role. ${ }^{13}$ Finding the right witnesses was both an exercise of network reaffirmation and a process in which geography and physical proximity were essential. The witnesses not only served as guarantors of the legitimacy of the donation, but they also had to meet for the declaration recorded by the tabellio, who confirmed their identities at the end of the donation with a short roster of witnesses known as a notitia testium, labeled in this early example as notitia testium id est: this is a record of the witnesses. ${ }^{14}$

Each witness followed the same formula as the first, Ioannes, in stating that he was present and that having been asked by Stephanus to attend, declared that: »I signed as a witness in his presence, and I saw that the donation was handed over in the presence of the representatives of the holy church of Ravenna."Because we have the closing of the donation we also know the location in which they likely met: in the outskirts of Rome at the "fourth district, " where the "office" of the tabellio Theodosius was located. ${ }^{15}$ Beyond their presence in

11 Aemilianus: PLRE III, 19 and Aemilianus 3 in PIB I,103; Constantinus 10 in PLRE III, 344 and Constantinus 12 in PIB I, 311-2; Leo 3 in PLRE III, 768 and Leo 14 in PIB II, 270; Maurentius 2 in PLRE III, 852-853 and Maurentius 2 in PIB II, 353; and Severus 4 in PLRE III, 1140.

12 Schoolman, Vir clarissimus and Roman titles, 6-7.

13 Schoolman, Local networks and witness subscriptions.

14 The notitia testium becomes a regular feature of Ravenna's later early medieval parchment and papyri, of which this example from Rome is a geographic and chronological outlier. Schoolman, Vir clarissimus and Roman titles, $15-24,33$.

15 P.Ital 18-19.B58-9, habens stationem in porticum de Subora, reg(ione) quarta. 
that place, each wrote his own subscription, a fact that did not limit the number of witnesses to those who could write but rather underscored the cultural and political groups to which they collectively belonged.

The papyrus contains the written testaments of five witnesses who subscribed to the production of the document:

Ioannes, domesticus numeri Dacorum

Vasacius, vir clarissimus

Chrisogonus, vir clarissimus and cancelarius

Marinus, vir honestus

Dominicis, vir clarissimus and optio numeri Sermisiani

Their identities, and their titles or the position for those that listed them, are reaffirmed in the notitia testium at the close of the record. From this list, two of Stephanus's witnesses were clearly soldiers, Ioannes and Dominicis. Although the order in which they subscribed may prove to offer some guide as to the hierarchy of the group, Ioannes, as a domesticus, stands out. ${ }^{16} \mathrm{He}$ is the only one without a title, even missing the low rank of honestus that commonly served as a sign of the legal ability to witness legal proceedings, but his rank as domesticus and the name of his unit, the numerus Dacorum, offer some insight. Domesticus was a lower grade officer in the seventh-century Byzantine Italian force, and because it could signify one of two different positions, here it likely indicated that Ioannes was the second-in-command of the numerus, a unit of 200 to 400 men typically led by a tribunus. ${ }^{17}$

The name of numerus Dacorum, the military unit to which Ioannes belonged, had a rich history long before the seventh century. Although it is likely that there were multiple iterations, the origins of the first unit called Dacorum date to the beginning of the second century, raised by Trajan or Hadrian in Dacia, and had been posted at locations across the Roman Empire. In 127, a diploma from Britain refers to Aelia Dacorum milliaria, and later inscriptions suggest that the unit was garrisoned at Hadrian's Wall in the third century. ${ }^{18}$ Greek inscriptions from Syria point to the existence of a $v \cup \mu \varepsilon$ po $\Delta a \kappa \tilde{\omega} v$ stationed in Syria in the fifth or sixth century, notably a tombstone of its commander, the tribunus Asterius, found in Apamea. ${ }^{19}$ Because Dacia was lost to the Byzantines by 580 , and the unit must have been raised before that point, it seems likely the numerus was later transferred to Italy, perhaps after its stay in Syria. By the beginning of the seventh century, it was just one of many units garrisoned there described as either numerus or bandus. ${ }^{20}$ 
The other witness who clearly belonged to the Byzantine military was Dominicis. Unlike Ioannes, he was styled with the rank of vir clarissimus, a title that once served to mark inheritable senatorial status but by the end of the sixth century had been applied to many members of the military and administrative service as well as to local urban elites. ${ }^{21}$ It was also the title that had the greatest continuity in the documents from Italy, and is found into the tenth century (although applied through very different criteria and only regularly in documents from Ravenna). Three other witnesses to Stephanus's donation were also clarissimi, Chrisogonus, Vasacius, and Marinus, and it is likely that they all had some official capacity, although only in the case of Chrisogonus was it expressly listed.

The connection between Dominicis and Ioannes was not just in their military service, but also in the origins of their units. Dominicis served as optio, or commander, of what had been a unit originally formed from foederati of foreign mercenaries and raised from northern Pannonia, specifically the area around Sirmium. ${ }^{22}$ Although the unit is not mentioned elsewhere, given the same fate as Dacia it must have existed earlier in the sixth century, and been established in Italy by the early seventh. The position of commander of this exact unit is mentioned a second time in the Italian papyri in the registration of a donation made in Rome contemporary to that of Stephanus. That donation described a gift of land to the "servants" of the Church of Sancta Maria ad Praesepe (now Santa Maria Maggiore) in Rome by a daughter of imperial secretary Megistus and listed the witnesses, including Georgius, optio numeri militum Sermisiani (P.Ital 17.31-2). ${ }^{23}$

The final witness who suggests the breadth of Stephanus's network was the cancelarius Chrisogonus. ${ }^{24}$ The role of cancelarius (or cancellarius) in the sixth century was relatively low status. In Cassiodorus's Variae, he includes a letter to a cancellarius Iohannes, in which he praised the man for advancing in ability beyond his position in the official hierarchy. ${ }^{25}$ By the seventh century, the position remained that of a functionary who served the administration, normally under a higher-ranking official, including examples where they served a praetor, iudex, and notarius, but was clearly a bureaucratic rather than military position.

What we can take away from this group of witnesses is that Stephanus chose men of lesser status and rank to legitimate his donation, men who had served the administration of Italy and could have been his past or current subordinates. The selection of two officers attached to units with origins on the eastern Latin frontier indicates that he had connections to those units, perhaps serving as magister militum overseeing both. More concretely, his selection of these officers along with the recipient of the donation, the church of Ravenna, also further binds him to the Byzantine administration. Despite the fact he was a grecus, he belonged within the same structures of authority as his Latin-speaking (or at least Latin-writing) witnesses.

Yet, he also belonged to another group, one that used Greek script either by choice or by necessity. This is apparent in how Stephanus wrote his own confirmation of the donation, which while in Latin, is transcribed in Greek script (table 2).

Schoolman, Vir clarissimus and Roman titles.

On the position of optio, which originally designated »quartermaster, « see Brown, Gentlemen and Officers, 59-60.

Ravegnani, Le unità dell'esercito bizantino, 201-202.

Chrysogonus 6 in PIB I, 296.

Cassiodorus Variae, XI.6.2. 
Table 2: Subscription of Stephanus (P.Ital 18-19, 18-28)

\begin{tabular}{|c|c|}
\hline Original text & Transliteration to Latin Script \\
\hline 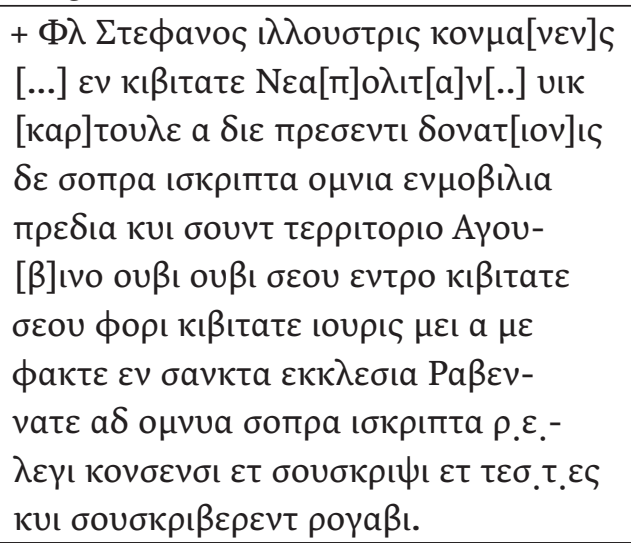 & $\begin{array}{l}\text { + Fl. Stefanos Illoustris conmanens } \\
\text { [...] in civitate Neapolitan[... uic } \\
\text { cartoule a die presenti donationis } \\
\text { de sopra iscripta omnia inmobilia } \\
\text { predia cui sount territorio Agou- } \\
\text { bino oubi oubi seou entro civitate } \\
\text { seou fori civitate iouris mei a me } \\
\text { facte en sancta ecclesia Raven- } \\
\text { nate ad omnia sopra iscripta re- } \\
\text { legi consensi et souscripsi et testes } \\
\text { cui souscriverent rogavi. }\end{array}$ \\
\hline
\end{tabular}

To form this kind of transliteration, it must have been the case that Stephanus was a fluent writer of Greek and had been trained as such, but likely did not have that capacity in Latin, or he acted as if he was essentially illiterate or unlettered in Latin script. Despite the relative flexibility of the form of the donation, Stephanus was being fed the proper Latin formula, and while he spoke and listened, he also transcribed the text.

Transcriptions like these are useful in illustrating the qualities of early medieval Latin and Romance vernacular, such as the continuity of dropping of the "n « in "iscripta" (for "inscripta «), a feature of modern Italian that dates back to the Oscan and Umbrian languages. ${ }^{26}$ Furthermore, the phonology does not seem to represent a version of grecicized Latin, but likely a longstanding local Latin dialect with these features.

In this case, the use of this script is emblematic of the acceptance and even preference of certain individuals to use Greek script in the production of legal documents: while the entire proceedings of many of these events took place in Latin, these byproducts suggest that Stephanus was able to signal a difference though his script, using graphical representations to confirm aspects of his status and identity. Stephanus was not alone in this regard. While the alternative phenomenon of writing Greek in Latin script had been long attested in the papyri from Egypt, it is primarily the documents from sixth and seventh century Italy that provide evidence for this particular type of graphical switching, writing Latin in Greek script, although there are a few notable earlier examples and the practice becomes common in southern Italy from the ninth century on.

26 The loss of the - $n$ - is also a feature of Oscan and Umbrian, Buck, Grammar of Oscan and Umbrian, 70-71. Illustrations of the conservative elements of various aspects of the phonology of this Latin as found in Greek transcriptions extends to other examples, such as $\beta$ for v noted at the beginning of the Common Era in Nishimura, Notes on Glide Treatment, 199-200. 
Perhaps the best studied of the early examples was written in Ravenna (but preserved in Egypt), a receipt for the sale of a slave of Asechines Flavianus to T. Memmius Montanus, who served in the Ravenna fleet. James Adams has carefully reviewed this document in its entirety, which features the Latin subscription of Asechines written in Greek script. ${ }^{27}$ Asechines was from Miletus, but his location in Italy and the fact that he seemed to have "awareness" of Latin morphology suggests that he had more than a simple familiarity with the language. In taking the whole of the errors and choices made, Adams concluded that although »the text is formulaic, Aeschines' own input can be detected, and this input provides evidence for the language use of a Greek with imperfect command of Latin as a second language. ${ }^{28}$

Because he both dictates the formula of the donation and then subscribes, the case of Stephanus suggests that his Latin was much more fluent than his Greek predecessor Asechines. Similarly, the possibility that Stephanus commanded units in the west also underscores a facility with Latin, but serving in the military was not the primary condition in which we find graphical switching. In fact, even though the total number of papyri from Italy is small, more than $10 \%$ have Latin written in Greek script, or a hybrid form of the two, and the case of Stephanus is the only one that indicates the practice extended to those in high-ranking administrative positions.

In 58 examples of non-literary papyri documents in the corpus, the use of Greek script for the subscriptions of witnesses appears in six instances excluding that of Stephanus, dating back to the first years after the Byzantine conquest of Italy (table 3).

Table 3: Witnesses using Greek Script in the Italian Papyri

\begin{tabular}{|c|c|c|}
\hline Text and type & Date & Witness \\
\hline $\begin{array}{l}\text { P.Ital } 30,92-97 \\
\text { Bill of sale }\end{array}$ & 539 & 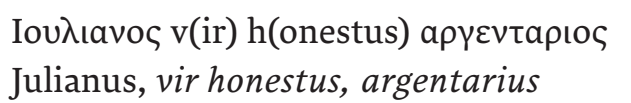 \\
\hline $\begin{array}{l}\text { P.Ital } 36,55-58 \\
\text { Bill of sale }\end{array}$ & $575-591$ & 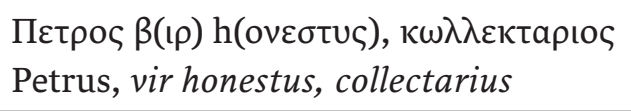 \\
\hline $\begin{array}{l}\text { P.Ital } 37,78-83 \\
\text { Bill of sale }\end{array}$ & 591 & 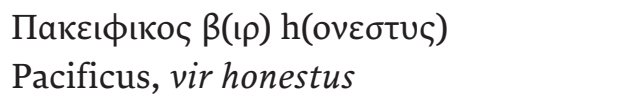 \\
\hline $\begin{array}{l}\text { P.Ital 16, 38-49 } \\
\text { Donation to the church of Ravenna }\end{array}$ & c. 600 & 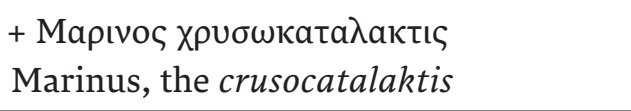 \\
\hline $\begin{array}{l}\text { P.Ital 20, } 83-90 \\
\text { Donation to the church of Ravenna }\end{array}$ & c. 600 & 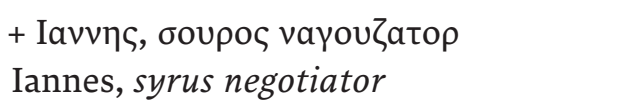 \\
\hline $\begin{array}{l}\text { P.Ital } 24,9-20 \\
\text { Donation to the church of Ravenna }\end{array}$ & $\begin{array}{l}\text { mid-70os } \\
\mathrm{AD}\end{array}$ & $\begin{array}{l}{[\ldots . . .] \mathrm{v}(\mathrm{ir}) \mathrm{h} \text { (onestus) }} \\
\text { a vir honestus [the remaining subscrip- } \\
\text { tion is in Greek script] }\end{array}$ \\
\hline
\end{tabular}

27 Adams, Bilingualism and the Latin Language, 53-63.

28 Adams, Bilingualism and the Latin Language, 61. 
These examples prove instructive as at least pointing to the groups engaged in this type of graphical code-switching, which only appears when witnesses or participants are required to subscribe to the closing of a legal agreement.

Out of the six other examples, four labeled themselves as viri honesti, in its abbreviated form, sometimes in Latin script, others in Greek or what appears to be a hybrid. According to Tom Brown, as a rank honestus was "predominantly ... applied to all well-to-do laymen who did not possess an official honor, including artisans, traders and notaries as well as landowners. The main characteristic of an honestus was his full judicial capacity ..." including the ability to act as a witness in court and subscribe to legal documents, which our writers exercised here. ${ }^{29}$ The title seems to have also been connected to Justinianic legislation, on the basis of the evidence from the documentary sources as well as those from legal statutes, the positions covered by honesti were similar to those who benefited from the exemption of civic duties named in Codex Iustinianus X.66.1, after an edict of Constantine from 337, and who included, among others, artisans such as sculptors, doctors, and even bankers (well represented in the examples above). ${ }^{30}$

Only four can be identified by their occupations. Three of these men were bankers or provided money-changing services of various types and one was a negotiator, an occupation which seemed to blend the divisions between trading, banking, and the wholesale distribution of goods. And in fact, Greek speakers or those with origins in the east as a whole were overrepresented in banking and finance, especially in Ravenna where our documentation is the strongest. ${ }^{31}$

The individual who held the occupation of argentarius and served as a witness in the sale of 539, and therefore was also the earliest of the witnesses to write in Greek, shared a name and title with one of the most well-known patrons of the mid-sixth century: the argentarius Julianus, who paid for the construction of San Vitale in Ravenna and Sant'Apollinare in Classe, among other churches according to the Liber pontificalis of Agnellus. Julianus operated in Ravenna in the first years after the fall of the Ostrogothic kingdom during the subsequent Gothic war and establishment of Byzantine rule, operating both as a banker and lender but likely also involved in commercial ventures as agentarii had long done. Although the title originally referred to silverwork, it had evolved to describe a position with a wide range of banking activities in the first and second centuries; yet it could be applied to a number of different situations and with a great degree of flexibility. ${ }^{32}$ In the case of Julianus, he may also have served in a government capacity, financing state enterprises through loans to taxpayers, or provided needed liquidity during the Gothic wars. ${ }^{33}$ Whatever the source of his income, his position allowed him to accumulate enormous wealth, to the point that he was

29 Brown, Gentlemen and Officers, 213-214.; see also Patlagean, Les armes et la cité à Rome, 48-52.

30 Schoolman, Vir clarissimus and Roman titles, 8-9.

31 Brown, Ebrei e orientali a Ravenna, 139-140.

32 Andreau, Banking and Business, 33-34. By the end of the sixth century, the title of argentarius would return to being applied to silversmiths who were not professionally lending money. Using Gregory Epistolae XI.16, Lopez, An Aristocracy of Money , 23, noted that: »Pope Gregory the Great was forced to intervene to save from bankruptcy the last argentarius doing business as a banker in Rome; the argentarii who are mentioned after that time seem to have been ordinary silversmiths." On the development of the terminology, see Roueché, Aurarii in the Auditoria.

33 Barnish, The Wealth of Iulianus Argentarius, esp. 34-36. Iulianus 7 in PLRE III, 730-1. 
able to contribute 26,000 solidi to the construction of San Vitale. ${ }^{34}$ That Julianus held Greek in a privileged position is visible in his patronage through the placement of a monogram of Iouגıavo in San Vitale, reaffirming his status as a member of the recently reinstalled elite from the East. ${ }^{35}$

Whether the Julianus argentarius who sponsored churches in Ravenna was one and the

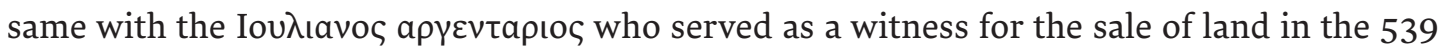
papyrus ( $t a b .3$, no. 1) is unclear. ${ }^{36}$ They had much in common, however, as both preferred to use Greek script if not Greek language, but the contexts where they were put to use differed. For the patron, supporting the churches of Ravenna was both a sign of his wealth and a manifestation of his civic euergitism, and his monogram (placed alongside that of the emperor Justinian) rightly signaled his status and allegiances.

For Iouגıavo the witness, something else was at play. The 20-iugera of land was being sold by a mother, Thulgilo, and her children, Dominca and Deutherius; Deutherius was, like many of the witnesses, a vir honestus. The buyer was Pelegrinus, who must have been of some means, as the agreed price of 110 gold solidi indicates wealth, and some of his wit-

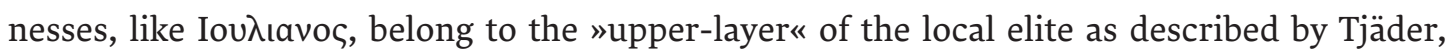
although others seem to have been lower-ranking officials. ${ }^{37}$ Furthermore, Thulgilo has a clearly Gothic name, and one of the witnesses, Latinus, may have subscribed to another document with a Gothic name, so the group in total represents the diversity of post-conquest Ravenna. It is in this milieu that Iouגıavos as a witness belongs, certifying the porous nature of local elites at that moment.

One further note of information about Iovilavo is that the notitia testium offers another distinguishing feature (which perhaps could have been used to differentiate him from the patron and argentarius Julianus), that he was the gener lohanni pimentari (P.Ital 30.109), the

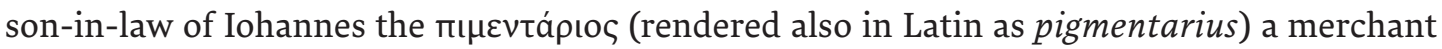
who traded in spices and unguents, or less likely also colors and paints, and who would have maintained strong links to the eastern Mediterranean through his professional contacts.

We have less information about the other witnesses, but they all likely operated within similar contexts. Petrus ( $t a b .3, n o .2$ ) was a collectarius, an occupation well-attested in the papyri of Italy that served to benefit a local administration by specific kinds of currency exchange. Tom Brown has identified this as "collecting in gold coins on behalf of the state from the public in return for copper. $\aleph^{38}$ Petrus appeared as a witness to the sale of half a fundus from the honestus Deusdedit to the clarissimus Hildigernus for 14 solidi; he was selected owing to his connection to the local government, or as the notary added, he was located ante custodia charceris, in front of the local jail (P.Ital 36.67). Marinus, who subscribed to a dona-

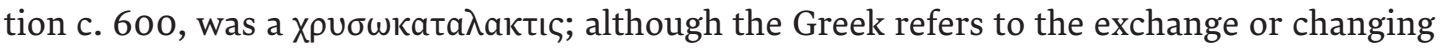

This amount was, however, a miniscule amount compared to the cost of Hagia Sophia in Constantinople, for example. Laiou and Morrisson, Byzantine Economy, 187-88.

35 Deichmann, Ravenna, vol. 2, 21-27.

36 The Iou $\lambda$ ıavos from this papyrus is mentioned under Iulianus 7 in PLRE III, 730-1. Likewise, they share an entry as Iulianus 12 in PIB II, 233.

37 Tjäder, Die nichtliterarischen lateinischen Papyri Italiens, vol. 2, 56, „Die Zeugen gehören zum Kreis der niedrigen öffentlichen Diener und der oberen Schicht der Bürgerschaft.«

38 Brown, Gentlemen and Officers, 77. 
of gold, it would be synonymous with argentarius in terms of the main activities, changing lower types of currency into more valuable ones or vice versa, an undertaking that was more of a banking role than the collectarius. ${ }^{39}$ What is clear is that Petrus was serving as a witness at least 40 years after the Byzantine occupation of Ravenna, and Marinus at least 65 years later, which indicates that administrators were either still being recruited from the East or, less likely, that those descended from the first generation maintained a preference for Greek even in terms of writing.

There are a number of reasons to support the first position, of the continued arrival of Greeks, as opposed to the second, that in communities with large numbers of Latin speakers, second-generation elites continued to learn the script as well as speak Greek. The first is a relatively common feature in all of the subscriptions, in which formulaic Latin abbreviations are rendered even in Greek characters. The example of the subscription of Marinus has another interesting feature, a case in which the Greek-writing subscriber seems to be following a written formula. In his subscription to P.Ital 16, in his first two lines he writes:

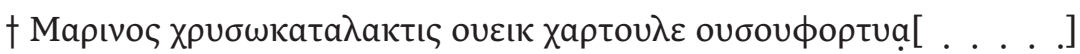

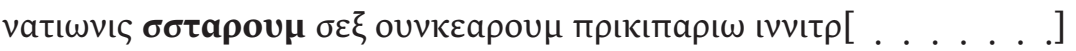

The form $\boldsymbol{\sigma \sigma \tau \alpha \rho o u \mu}$ is nothing other than a partial abbreviation of $\mathbf{s}$ (upra)s(crip)tarum, which is the form generated by the other witnesses..$^{40}$ In the example of Petrus's subscription, he first has trouble with rendering his own title in Greek and resorts to a hybrid abbreviation with a $\beta$ representing the "V« in vir and a Latin "h" for honestus (this is what Pacificus, or rather Паквıфıкос, another Greek-writer also did), as well as offering $\sigma \sigma$ for all forms of superscriptus where the Latin writers would often indicate the case endings. These instances demonstrate that most witnesses were working from a formula, and even if they had familiarity with Latin, there was sometimes difficulty in rendering the Latin in a consistent way.

Yet more persuasive is that one Greek-writing witness, the negotiator Ioannes, offered a glimpse of additional differentiation, as he also used the term syrus as a mark of his origins, either by birth or by heredity. Like Stephanus, this application of syrus in the Latin papyri is a hapax, only appearing in this instance, but when taken with the example of Stephanus's grecus supports the position that origins were included in the production of these agreements, perhaps as a way of differentiating two individuals or more likely to follow a self-declaration.

As with Stephanus, the names of these men give nothing away as to their political identity. They were simply common names, although some had derivations not in Greek or Christian

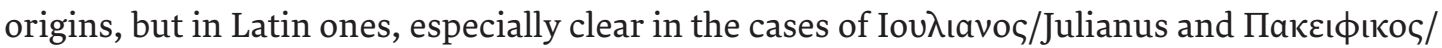
Pacificus. But unlike Stephanus, who belonged to a higher social and occupational category altogether, none of these men describe themselves, or are described, as grecus.

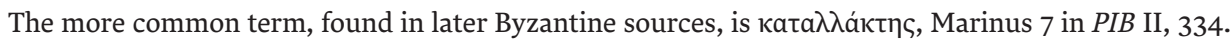

40 This was noted in the commentary of Tjäder and recognized as a feature in medieval charters in von Falkenhausen, Medieval Neapolitan document, 178. 
Instead of using grecus to describe the origins or heredity of individuals, the term appears more commonly to be a descriptor for the use of Greek script, which becomes clear in the case of a fragmentary papyrus register that collected the records of a number of openings and executions of wills. In one will (from between 552 and 575) a witness confirmed being present at the will's creation and that he recognized his signature "in Greek letters" (grecis litteris), and then further subscribes to its authenticity. ${ }^{41}$ The notary recorded the statement of Theodolus, a silk merchant (olosiricoprata), during the opening of the will of Georgius who shared the same occupation: »Theodolus, vir clarissimus, silk merchant said: I am present here willingly; I recognize on this document the seal of my ring, and the things I wrote above in Greek letters (grecis litteris), and I subscribe to this below." In that same collection of wills, at least two other individuals acknowledged their Greek letters, although the papyrus does not preserve anything further about their identities. ${ }^{42}$

In fact, in the early Italian papyri, the Latin adjective grecus is used almost exclusively to describe not only script, but also written language. The best evidence is preserved in a very early list of charters held by the treasurer of the praetorian prefect in Ravenna, created after 510. In this case, out of the 44 documents listed, four are described as being in Greek:

Line 5a: Another cautio of Macedonius in Greek made on the behalf of Peter for 1100 solidi.

Line 23a: A cautio in Greek of John, and John addressed to Peter for 1000 solidi in the consulship of Boethius the Younger, vir clarissimus ( = 510 AD).

Line 27a: A cautio made in Greek of Paul addressed to Peter for solidi numbering 100 and [....] in the consulship of Venantius ( = 507 AD).

Line 16b: Greek letter addressed to Peter. ${ }^{43}$

These listings, for a letter and three cautiones, a type of legal document guaranteeing future payment, all seem to be connected to a certain Peter, who may have had them entered together into the archive along with other documents related to his ventures, although given the limits of the text and its preservation, there can be no certainty.

All these examples demonstrate a certain kind of migration of Greek speakers to Italy, and one that pre-dated the conquest of Italy under Justinian, although significantly more conspicuous and better documented in the second half of the sixth century. What the donation of Stephanus suggests is that there would have been a great deal of individual mobility, at least within the territory under Byzantine control, although much of this is undocumented and likely undocumentable. The case of Stephanus, however, illustrates various links and paths that were likely well-travelled. Through his donation, we know that he owned land around Gubbio,

41 P.Ital 4-5.B8, Theodolus v(ir) c(larissimus) olosiricoprata d(ixit): pleriquae et ego interfui in hac voluntate, in qua agnosco anuli mei signaculum, superscribtionem meam grecis litteris, et infra subscribsi.

42 P.Ital 4-5.A1 and A5.

43 P.Ital 47-8.A5, cautio Macedon[i a]lia greca facta ad n(omen) Petri sol(idorum) mille cento. P.Ital 47-8.A23, cautio greca Iohannis et Iohannis ad n(omen) Petri sol(idorum) M Boethio Iun(iore) v(iro) c(larissimo) consul(e).

P.Ital 47-8.A27, c.[au]tio greca Pauli facta ad nom(en) Petri sol(idorum) n(umero) C[ . . . . ] Ṿeṇenati[o] c.[onsu]le. P.Ital 47-8. B16, ẹ[p]istula greca facta ad nomen Petri. 
which he either received for his service or purchased, and likely visited. Whatever his level of service, he would have had to travel to Ravenna where the exarchs were based, and perhaps his career there (and the fact that it had remained the administrative capital) made his donation also a reconfirmation of his membership to its community. The donation itself was given in Rome, in front of a Roman notary, and with witnesses who presumably were relatively local. Why Stephanus chose to make his gift in Rome rather than in Ravenna or in Naples is elusive, but the fact that he was in a third location further underscores his mobility.

What also sets Stephanus apart from the other Greek writers was that in his subscription to his donation he confirmed his home, that he was conmanens [...] in civitate Neapolitan[...], "residing in the city of the Neapolitans." Both archaeological studies and contemporary sources dating back to Justinian's conquest offer some details about the city when Stephanus was a resident. New geomorphological and paleo-ecological reconstructions offer a glimpse into the city's development, with the establishment of new farmland in silted harbors to the west and the subsequent development of harbors to the east and the rise in visibility of chestnuts on the landscape, all in the fifth century. ${ }^{44} \mathrm{~A}$ broad synthesis of the archaeological data supports the idea that commerce and manufacturing remained strong in the city during Late Antiquity, especially after the fifth-century decline of what had been Campagna's main port, Puteoli. ${ }^{45}$

Reference to Naples' continued trade in the first half of the sixth century, and with it connections to the east, appear as an anecdote in Procopius's Gothic Wars. On the eve of Belisarius's attack against the city on which he had set siege (on account of the fact that it had been favorable to Ostrogothic rule), the Neapolitans sent out a man named Stephanus, who debated with Belisarius about the fate of the city but ultimately returned to attempt reconciliation and convince the Neapolitans to accept Justinian's forces. In describing his exhortations to avoid battle through capitulation, Procopius offered this aside: "Stephanus reported the speech of Belisarius and expressed his own opinion that it was unwise to fight against the emperor. He was assisted in his efforts by Antiochus, a Syrian man who had long been resident in Naples for the purpose of carrying on a shipping business, who had a great reputation there for wisdom and justice. ${ }^{46}$ Although others would successfully argue against Stephanus and Antiochus, the fact that even during the Ostrogothic dominion of Italy, cities like Naples and Ravenna drew foreigners like Antiochus and Julianus and his father (described above), explains a crucial feature. These communities did not form with the arrival of Justinian's armies, but rather grew out of those predating the sixth century, and were originally composed of Greeks concerned with mercantile and banking interests that later incorporated soldiers and administrators working directly for the exarchate.

44 Russo Ermolli et al., Natural and cultural landscape of Naples, 408-409. On the importance of chestnuts in early medieval Italy, see Squatriti, Landscape and Change.

45 Arthur, Naples, from Roman Town to City-State; Arthur, Naples: A Case of Urban Survival.

46 Procopius, Gothic Wars V.8. Trans. after Dewing. 
During the Gothic wars, Naples fared poorly, suffering a year-long siege by Totila that ended with the city's capitulation and the raising of its walls. Procopius noted that Totila treated the citizens and the Byzantine garrison fairly, and by the end of the sixth century we can see that Naples had resumed its trade connections in the letters of Pope Gregory, but larger problems of cohesion remained. The Liber pontificalis described that in the early seventh century, during the papacy of Deusdedit (615-618), an independent commander appeared, John of Compsa (or Conza), who was later removed by the exarch Eleutherius. Finally, in 663, Naples welcomed the emperor Constans II as he travelled through Italy. This history, of Naples being pulled toward Byzantine rule, the papacy, and its own independence would continue until the middle of the eighth century. Its citizens reflect the influence of these various forces, and perhaps these are at play in the physical mobility of the magnificus Stephanus and his choice for the recipient of his donation.

Ultimately, grecus as applied to Stephanus must not only be understood as a personal quality, but also as a part of his larger identity. His titles of magnificus and illustris place him within the reestablished Byzantine military and administrative hierarchy in operation in Italy in the late sixth and early seventh centuries. The invocation of grecus as recorded by the notary and reiterated by the witnesses, clearly positions him as a member of a minority linguistically or ethnically - and along with his focus on the church of Ravenna as a member of an administration sent from afar. The use of Greek for his subscription, if a choice rather than out of necessity, connects to an observation made by Adams: "Some writers using Greek characters for the Latin Language did so not because they were unable to use Latin script, but because they chose to transliterate on a particular occasion. « ${ }^{47}$ Including the now unnamed witness to P.Ital 24, a donation of a garden in the city to the church of Ravenna made by Gaudiosus, vir reverentissimus and defensor sanctae ecclesiae Ravennatis, in the middle of the seventh century, Stephanus would be the last to use Greek in extant documents until the ninth and early tenth centuries, when Greek writers reappear in the case of the earliest surviving Neapolitan charters. ${ }^{48}$

Although he may have been a grecus, he was also a citizen of Naples, a magnificus, a donor to the church of Ravenna, and a man who could rely on military commanders to legitimate his gift. Yet among all these attributes, the self-reference as grecus was crucial, a micropolitical act that excluded Stephanus from the Latin speakers and writers and grouped him among an elite cohort of "Romans « not from Italy but from the east, sent by Constantinople to defend and govern Italy in the wake of the arrival of the Lombards.

47 Adams, Bilingualism and the Latin Language, 43.

48 Schoolman, Local networks and witness subscriptions, 39. On Greek subscriptions in the charters from Naples in the ninth and tenth century in general, Luzzati Laganà, Le firme greche, and von Falkenhausen, I documenti napoletani; for one of few surviving original charters, see von Falkenhausen, Medieval Neapolitan document. 


\section{Acknowledgements}

This article is part of a larger study on Greeks and the appearance of Greek identity in early Medieval Italy (500-1000), research for which was undertaken on the Wolfgang Fritz Volbach-Fellowship at the Leibniz-WissenschaftsCampus Project (RGZM, Mainz) in the Summer of 2017, as a visiting researcher in DiSSGeA (University of Padua) in the fall of 2017, and as a member of the DFG Center for Advanced Studies group on "Migration and Mobility in Late Antiquity and the Early Middle Ages« (Eberhard Karls Universität Tübingen) in the spring and summer of 2018. I would also like to acknowledge the financial support of the Office of the Provost and the Office of the Vice President for Research and Innovation at the University of Nevada, Reno. 


\section{References}

Adams, J. N., Bilingualism and the Latin Language (Cambridge, 2003).

Amory, Patrick, People and Identity in Ostrogothic Italy: 489-554 (Cambridge, 1997).

Andreau, Jean, Banking and Business in the Roman World, translated by Janet Lloyd (Cambridge, 1999).

Arthur, Paul, Naples, from Roman Town to City-State: An Archaeological Perspective (London, 2002).

Arthur, Paul, Naples: A Case of Urban Survival in the Early Middle Ages?, Mélanges de l'Ecole française de Rome, Moyen-Age 103 (1991) 759-784.

Barnish, S. J. B, The wealth of Iulianus Argentarius: Late antique banking and the mediterranean economy, Byzantion 55 (1985) 6-38.

Brown, Thomas S., Ebrei e orientali a Ravenna, in: Antonio Carile (ed.), Storia di Ravenna: II.1 Dall'età Bizanina all'èta Ottoniana: Territorio, economia e società (Ravenna, 1991) 135-154.

Brown, Thomas S., Gentlemen and Officers: Imperial Administration and Aristocratic Power in Byzantine Italy A.D. 554-80o (Rome, 1984).

Brown, Warren, On the Gesta municipalia and the public validation of documents in Frankish Europe, Speculum 87 (2012) 345-375.

Buck, Carl Darling, A Grammar of Oscan and Umbrian (2nd edition), (Boston, 1928).

Cameron, Alan, Flavius: A nicety of protocol, Latomus 47 (1988) 26-33.

Cassiodorus Variae = Magni Avrelii Cassiodri, Variarum libri XII, ed. Åke Jason Fridh, in: Magni Avrelii Cassiodri Senatoris, Opera, vol. 1, CCSL 96 (Turnhout, 1973).

ChLA $=$ Chartae Latinae antiquiores: facsimile edition of the Latin charters prior to the ninth century, ed. Albert Bruckner and Robert Marichal, vol 1-114 (Olten, 1954-2013).

Crosara, Fulvio, P. Tjäder 18-19AB e la Chiesa ravennate, in: Antonio Guarino and Luidi Labruna (eds.), Synteleia Vincenzo Arangio-Ruiz (Naples, 1964) 696-699.

Deichmann, Friedrich Wilhelm, Ravenna: Hauptstadt des spätantiken Abendlandes, 3 vols (Wiesbaden, 1958-1989).

Dubuisson, Michel, Graecus, Graeculus, Graecari: L'emploi péjoratif du nom des grecs en

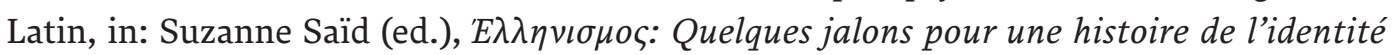
grecque (Leiden, 1991) 315-335.

Everett, Nicholas, Lay documents and archives in early Medieval Spain and Italy, c. 400-700, in: Warren Brown, Marios Costambeys, Matthew Innes and Adam Kosto (eds.), Documentary Culture and the Laity in the Early Middle Ages, (Cambridge, 2013) 63-94.

Gregory, Epistolae = Gregorius Magnus, Registrum epistularum, ed. Dag Norberg, CCSL 140104a (Turnhout, 1982).

Guillou, André, Régionalisme et indépendance dans l'Empire Byzantin au VIIe siècle (Rome, 1969).

Holder, Paul, Auxiliary units entitled Aelia, Zeitschrift für Papyrologie und Epigraphik 122 (1998) 253-262.

Kaldellis, Anthony, Hellenism in Byzantium: The Transformations of Greek Identity and the Reception of the Classical Tradition (Cambridge, 2008).

Koder, Johannes, Griechische Identitäten im Mittelalter - Aspekte einer Entwicklung, in

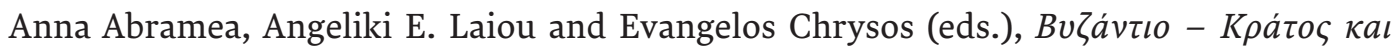

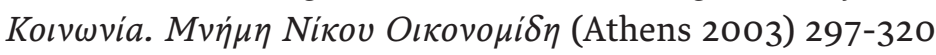


Koder, Johannes, Sprache als Identitätsmerkmal bei den Byzantinern: Auf -isti endende sprachenbezogene Adverbien in den griechischen Quellen, Anzeiger der philosophischhistorischen Klasse 147 (2012) 5-37.

Laiou, Angeliki E., and Cécile Morrisson, The Byzantine Economy (Cambridge, 2007).

Lopez, Robert Sabatino, An aristocracy of money in the early Middle Ages, Speculum (1953) $1-43$.

Luzzati Laganà, Francesca, Le firme greche nei documenti del Ducato di Napoli, Studi Medievali, ser. 3. 23.2 (1982) 729-752.

Martin, Jean-Marie, Hellénisme politique, hellénisme religieux et pseudo-hellénisme à Naples (VIIe-XIIe siècle), Nea Rhome 2 (2005) 59-78.

Nishimura, Kanehiro, Notes on glide treatment in Latin orthography and phonology: -icio, servus, aio, Historische Sprachforschung 124 (2011) 193-209.

Patlagean, Evelyne, Les armes et la cité à Rome du VIIe au IXe siècle et le monde européen des trois fonctions sociales, Mélanges de l'Ecole française de Rome. Moyen-Age, Temps modernes 86 (1974) 25-62.

P.Ital = Die nichtliterarischen lateinischen Papyri Italiens aus der Zeit 445-700, ed. Jan-Olof Tjäder, vol. 1-2 (Lund, 1955; 1982).

PIB = Prosopografia dell'Italia bizantina: 493-804 (v. 1: A-F, v. 2: G-O), ed. Salvatore Cosentino (Bologna, 1996; 2000).

Pollard, Nigel, Soldiers, Cities and Civilians in Roman Syria (Ann Arbor, 2000).

PLRE II = The Prosopography of the Later Roman Empire, part II: AD 395-527, ed. J. R. Martindale (Cambridge, 1980).

PLRE III = The Prosopography of the Later Roman Empire, part III: AD 527-641, ed. J. R. Martindale (Cambridge, 1992).

Procopius, Gothic Wars = Procopii Caesariensis opera omnia, vols. 1-2, ed. Gerhard Wirth (Leipzig: 1962-1963); trans. H. B. Dewing, Procopius, History of the Wars, Volume III: Books 5-6.15, Loeb Classical Library 107 (Cambridge, MA, 1916).

Ravegnani, Giorgio, Le unità dell'esercito bizantino nel VI secolo tra continuità e innovazione, in: Stefano Gasparri (ed.), Alto medioevo mediterraneo (Florence, 2005) 185-205.

Roueché, Charlotte, Aurarii in the Auditoria, Zeitschrift für Papyrologie und Epigraphik 105 (1995) 37-50.

Russo Ermolli, Elda, Paola Romano, Maria Rosaria Ruello, and Maria Rosaria Barone Lumaga, The natural and cultural landscape of Naples (southern Italy) during the Graeco-Roman and Late Antique periods, Journal of Archaeological Science 42 (2014) 399-411.

Russo, Eugenio, La presenza degli artefici greco-costantinopolitani a Roma nel VI secolo, Jahreshefte des Österreichischen Archäologischen Institutes in Wien 75 (2008) 243-298.

Schoolman, Edward M., Local networks and witness subscriptions in early Medieval Ravenna, Viator 44 (2013) 21-41.

Schoolman, Edward M., Vir clarissimus and Roman titles in the early Middle Ages: Survival and continuity in Ravenna and the Latin West, Medieval Prosopography 32 (2017) 1-39.

Squatriti, Paolo, Landscape and Change in Early Medieval Italy: Chestnuts, Economy, and Culture (Cambridge, 2013).

Stouraitis, Yannis, Roman identity in Byzantium: a critical approach, Byzantinische Zeitschrift 107 (2014) 175-220. 
Stouraitis, Ioannis, Byzantine Romanness: From geopolitical to ethnic conceptions, in: Walter Pohl, Clemens Gantner, Cinzia Grifoni and Marianne Pollheimer-Mohaupt (eds.), Transformations of Romanness in the Early Middle Ages: Regions and Identities (Berlin, 2018) 123-139.

Tarozzi, Simona, La petitio faciendi tutoris specialis di Gundihild in P.Ital. 1,7, in: Gisella Bassanelli Sommariva and Simona Tarozzi (eds.), Ravenna Capitale: Territorialità e personalità (Santarcangelo di Romagna, 2013) 107-26.

Tjäder, Jan-Olof, Die nichtliterarischen lateinischen Papyri Italiens aus der Zeit 445-70o, vol. I. (Lund, 1955).

Tjäder, Jan-Olof, Die nichtliterarischen lateinischen Papyri Italiens aus der Zeit 445-70o, vol. II. (Lund, 1982).

von Falkenhausen, Vera, A medieval Neapolitan document, The Princeton University Library Chronicle 30 (1968-1969) 171-182.

von Falkenhausen, Vera, I documenti napoletani come fonte per lo studio delle interferenze Greco-Latine (IX-XII secolo), in: Rosanna Sornicola and Paolo Greco (eds.), La lingua dei documenti notarili alto-medievali dell'Italia meridionale: bilancio degli studi e prospettive di ricerca (Cimitile, 2012) 107-126.

Wolfram, Herwig, History of the Goths (Berkeley, 1988). 